\title{
Quantity inferences in conditionals: a pilot experimental study
}

\author{
Natalia Zevakhina, Veronika Prigorkina \\ International Laboratory for Logic, Linguistics and Formal Philosophy, National \\ Research University Higher School of Economics \\ https://doi.org/10.36505/ExLing-2020/11/0058/000473
}

\begin{abstract}
Relying upon Fillenbaum (1975), the paper reports on a more systematic experimental study of the role of the following factors (and levels) in the derivation of Conditional Perfection: negation (no negation, negation in an antecedent, negation in a consequent, negation both in an antecedent and a consequent), order of two clauses of a conditional sentence (if p, q; q, if p), and face vs. non-face speech acts (promises, threats vs. causals, temporals and contingent universals).
\end{abstract}

Keywords: quantity inference, Conditional Perfection, conditional, negation, face

\section{Introduction}

Quantity inferences which are derived on the basis of conditional sentences were coined as Conditional Perfection in Geis and Zwicky (1971), see the famous example: If you mow the lawn, I'll give you five dollars; inference: If you don't mow the lawn, I won't give you five dollars. Schematically, the example (1) has the structure 'if $\mathrm{p}, \mathrm{q}$ ' (where $\mathrm{p}$ and $\mathrm{q}$ are clauses) and the inference has the structure 'if not p, not q'. Relying upon Fillenbaum (1975), we conducted a more systematic study of the role of various types of speech acts and the role of negation in the derivation of Conditional Perfection. Additionally, we tested the role of clause order.

The first question (Question A) is whether the derivation of an inference from a negated antecedent and/or a negated consequent would take a time interval comparable to the processing of a conditional sentence with no negation. The prediction (Prediction $\mathbf{A}$ ) is that conditional sentences with no negation yield inferences faster than conditional sentences with single negation (that is negation in an antecedent or in a consequent), which give rise to inferences faster than conditional sentences with double negation (that is negation in both an antecedent and a consequent). In other words, the prediction is as follows: if $\mathrm{p}, \mathrm{q}>>$ if not $\mathrm{p}$, $\mathrm{q}$; if $\mathrm{p}$, not $\mathrm{q}>>$ if not $\mathrm{p}$, not $\mathrm{q}$. The reason for the prediction lies in that negation is time-consuming. The second question (Question B) is whether the processing of an order antecedent + consequent would take a time interval comparable to the processing of an order consequent + antecedent. The prediction (Prediction B) is that the derivation of inferences from conditional sentences with the direct order (that is

ExLing 2020: Proceedings of 11 th International Conference of Experimental Linguistics, 12-14 October 2020, Athens, Greece 
antecedent + consequent) takes a lesser timing than the derivation of inferences from conditional sentences with the inverse order (that is consequent + antecedent). In other words, the prediction is as follows: if $\mathrm{p}, \mathrm{q}>>\mathrm{q}$, if $\mathrm{p}$. The reason for this is that, intuitively, the inference derivation starts from an antecedent (that is has a form "if p, q") and in case of "q, if p" the hearer firstly changes the order of the clauses and secondly derives an inference, and this presumably takes extra time. The third question (Question C) was whether face speech acts facilitate the derivation of Conditional Perfection since they concern damage to or respecting the hearer's interests. The prediction (Prediction C) is that speech acts that involve face give rise to more inferences and take lesser timing than speech acts that lack face.

\section{Methods}

We distinguished among five types of speech acts: promises and threats (face), causal and temporal sentences (no face), contingent universals (no face). Each of the five types was constructed as statements with no negation, single or double negation presented in the direct or inverse order. Moreover, according to the research questions $\mathrm{A}, \mathrm{B}, \mathrm{C}$ and predictions $\mathrm{A}, \mathrm{B}, \mathrm{C}$, each of the five groups came into the following schematic varieties: 1) statements with no negation, with single negation, with double negation presented in the direct order: If p, q; If not p, q; If p, not q; If not p, not q; 2) statements with no negation, with single negation, with double negation presented in the indirect order: $\mathrm{q}$, if $\mathrm{p}$; $\mathrm{q}$, if not $\mathrm{p}$; not $\mathrm{q}$, if $\mathrm{p}$; not $\mathrm{q}$, if not $\mathrm{p}$.

Lexical contents of all sentences were different. Each of the schemas was represented in 2 versions distributed between 2 experimental lists. We did this to decrease a potential effect that some sentence might have had. We generated speech acts $\mathrm{x}$ order $\mathrm{x}$ negation $\mathrm{x} 2$ versions for each combination distributed between 2 lists, with 40 stimuli per list, see (1)-(4). We used an inference task, cf. Geurts and Pouscoulous (2009) a.o. Participants were presented with a conditional sentence on a slide followed (on the next slide) with the question whether it is possible to make an inference (Conditional Perfection) as well as with yes (key $G$ ) and no (key J) answers. There was a time interval of $10 \mathrm{sec}$ to read a conditional sentence and a time interval of $15 \mathrm{sec}$ to answer the question. The latter interval is maximum, that is, participants had to choose an answer within this interval and their reaction times were recorded. The experiment was conducted in Russian.

(1) Esli ty pol'još mne cvety, ja nakormlju tebja pirogami. Možete li $\mathrm{Vy}$ sdelat' iz etogo vyvod, čto esli ty ne pol'yoš mne cvety, ja ne nakormlju tebja pirogami?

'If you water my flowers, I will give you the pies. Would you infer from that that if you don't water the flowers, I won't give you the pies?' (Promise; If p, q) 
(2) Esli Anja ne nadenet šarf, ona zamjorznet na ulice. Možete li Vy sdelat' iz etogo vyvod, čto esli Anja nadenet šarf, ona ne zamjorznet na ulitse? 'If Anja does not put on her scarf, she will get freezed outside. Would you infer from this that if Anja puts on her scarf, she won't get freezed outside?' (Causal; if not p, q)

(3) Borja ne prinimaet zvonki s raboty, esli on otdyxaet na more. Možete li Vy sdelat' iz etogo vyvod, čto Borja prinimaet zvonki s raboty, esli on ne otdyxaet na more?

'Borja does not answer phone calls if he is having a sea vacation. Would you infer from this that Borja answers phone calls if he is not having a sea vacation?' (Temporal; not q, if p)

(4) Desertnoj vilkoj ne pol'zujutsja, esli v menju ne predusmotren desert. Možete li Vy sdelat' iz etogo vyvod, čto desertnoj vilkoj pol'zujutsja, esli v menju predusmotren desert?

'One does not use a dessert fork if the menu does not contain a dessert. Would you infer from this that one uses a dessert fork if the menu contains a dessert?' (Contingent Universal; not q, if not p)

46 fillers were statements which denote sequences of events and were followed with a question that violates the order of the events. They were expected to receive a definite "yes" response or a definite "no" response, see (5)-(6). 6 of them were presented at the beginning of the experiment in order to train participants for the further experimental materials. The same fillers were used in both lists.

(5) Denis polil cvety, prežde čem oni zavjali ot nedostatka vody. Možete li Vy sdelat' iz etogo vyvod, cto Denis polil cvety, a potom oni zavjali ot nedostatka vlagi?

'Denis watered the flowers before they withered because of the lack of water. Would you infer from this that Denis watered the flowers and then they withered from the lack of water?' (Expected answer is "no").

(6) Eva vyšla iz, kinozala prežde, čem kino zakončilos'. Možete li Vy sdelat' iz. etogo vyvod, cto Eva vyšla iz kinozala, a potom kino zakončlos'?

'Eva left the cinema before the movie ended. Would you infer from this that Eva went out from the cinema and then the movie ended?' (Expected answer is "yes").

Due to a big number of stimuli and fillers, each 20 items were followed with a small break for $10 \mathrm{sec}$ in order to give some rest for participants. The 
236 N. Zevakhina, V. Prigorkina

experiment was conducted via IbexFarm, which is a free online platform for conducting experiments. There were 68 participants ( 49 female, age range $=19$ 39 , mean age $=22$ ).

\section{Results}

Out of 2720 received responses, 80 responses were removed due to null answers and 238 responses were excluded due to the extraordinarily slow or fast RTs (>10000 ms and $<250 \mathrm{~ms}$ respectively). To analyze the results of the study, generalized mixed-effects model for yes/no-answers and linear mixedeffects model for RTs were used. Focusing on the stimuli only, the overall acceptance of Conditional Perfection was significantly high, with average $76.34 \%(\mathrm{p}<.001)$. Both for answers and RTs, the interaction between speech acts vs. negation was significant $(\mathrm{p}<.05)$, but not between negation vs. order or speech acts vs. order ( $\mathrm{p}>$.05). Pairwise comparisons among types of negation for answers and RTs revealed that double negation significantly facilitates the derivation of Conditional Perfection and is processed faster than the single negation or no negation $(\mathrm{p}<.01)$. This suggests that Prediction A was not fulfilled. One plausible reason for this is that in case of double negation, both clauses of a conditional are marked with negation and, in this sense, are parallel in processing. Another plausible reason is that if a sentence contains double negation, its quantity inference includes no negation, that is double negation is tantamount to affirmation (cf. $\neg \neg \mathrm{p}=\mathrm{p}$ ). Pairwise comparisons among the types of clause order for answers and RTs revealed no significant difference between direct vs. inverse types of order ( $\mathrm{p}>.05)$. Prediction B was not fulfilled. This means that the order factor does not seem to be relevant in the derivation of quantity inferences in conditionals. Finally, pairwise comparisons among speech acts for answers and RTs revealed that face speech acts facilitate the derivation of Perfection. Prediction $\mathrm{C}$ was fulfilled. This suggests that inferential reasoning is dependent upon the face factor.

\section{References}

Fillenbaum, S. 1975. If: Some Uses. Psychological Research 37, 245-260.

Geis, M.L., Zwicky, A.M.. 1971. On invited inferences. Linguistic inquiry 2, 561-566.

Geurts, B., Pouscoulous, N. 2009. Embedded implicatures?!? Semantics and pragmatics 2,1-34. 